\title{
The Effect of Adenine Adsorption on Zn (II) Electroreduction in Acetate Buffer
}

\author{
Dorota Gugała-Fekner
}

\author{
Faculty of Chemistry, Maria Curie-Sklodowska University, Lublin, Poland. \\ *Corresponding author: E-mail: gugala@poczta.umcs.lublin.pl
}

Received: 20-06-2017

\begin{abstract}
The paper presents the thermodynamic analysis of adenine adsorption on a mercury electrode in an acetate buffer at $\mathrm{pH}$ 3 and $\mathrm{pH}$ 4. Adsorption energy and constants were determined using the Frumkin isotherm and the virial isotherm. Stronger adsorption in the buffer at $\mathrm{pH} 3$ was observed in comparison to the buffer at $\mathrm{pH} 4$. Using cyclic voltammetry and Faraday impedance measurement, an inhibitory effect of adenine on the kinetics of $\mathrm{Zn}$ (II) ion electro-reduction was observed.
\end{abstract}

Keywords: Adsorption, isotherm electrosorption, differential capacity, adenine

\section{Introduction}

A fundamental issue of electro-chemistry, both applied and theoretical, is the adsorption of organic compounds on the interface of electrode - aqueous electrolyte solution.

The results of adsorption studies facilitate the description of the structure and properties of the double electric layer and may facilitate interpretation of the effect of the double layer on the kinetics of electrode processes. ${ }^{1-4}$

Among other things, the information can be used to improve the function of corrosion inhibitors, ${ }^{5-7}$ controllers of metal electro-precipitation, organic electro-synthesis ${ }^{8}$ or electro-analytical techniques..$^{9-11}$

Adenine and guanine are two most important purine nucleobases that are present in all nucleic acids. ${ }^{12}$ Purines consist of a pyrimidine ring fused with the imidazole ring. In the five-membered heterocyclic imidazole ring there are two nitrogen atoms. One of them is situated in position 7 (N7) and it is basic due to the fact that its lone electron

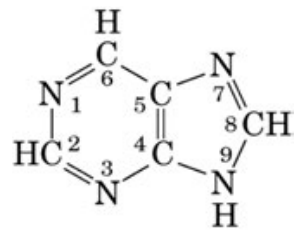

Figure 1. Structural formula of adenine. pair does not participate in the aromatic $\pi$ electron sextet. This nitrogen atom can be in unprotonated form. The other nitrogen atom of the imidazole ring (N9) is not basic because its lone electron pair participates in the $\pi$ electron sextet, analogically as in the case of the nitrogen atom in the pyrrole ring (Figure 1).

Problem behavior of adenine in acetate buffer was already taken by Xin Zao and all. ${ }^{13-15}$ There is no literature data concerning the behaviour of adenine in solutions at $\mathrm{pH} 3$ and 4, which encourages the studying of the adsorption of this compound. The selection of these $\mathrm{pH}$ values results from the fact that information concerning adenine adsorption will be used to study the kinetics of specific non-organic depolarisers, e. g. $\mathrm{Zn}$ (II), $\mathrm{Cd}$ (II) or $\mathrm{Pb}$ (II) ions in the presence of this organic compound. The basic electrolyte has to be a buffer solution because adenine used in the studies displays alkaline properties. The selected buffer is an acetate buffer which is poorly adsorbed on mercury.

The results presented in the work constitute part of the complex studies of the adsorptive properties of adenine, and its effect on the kinetics and mechanism of selected electrode processes.

Because of the wish to create a system extremely similar to the standard one, which is influenced by various thermodynamic dependencies, a dropping mercury electrode.

The mercury electrode is very close to the ideally polarizable electrode. That is because it has an almost ideally 


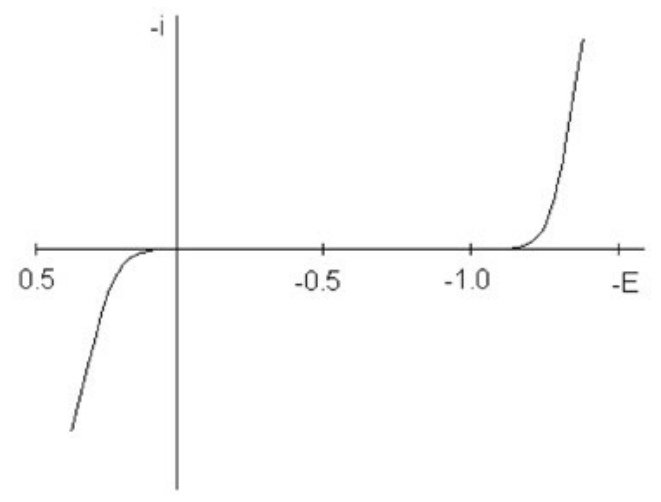

Figure 2. Polarization curve of the mercury electrode in $0,1 \mathrm{~mol} \mathrm{~L}^{-1}$ $\mathrm{HNO}_{3} \cdot{ }^{16}$

smooth and pure surface of mercury which is a liquid at room temperature. Figure 2 presents the polarization range of mercury electrode in an inert solvent.

The polarization range of the electrode is limited on the negative potentials side by decomposition of the main electrolyte (hydrogen is released) and on positive potentials side by electrochemical dissolution of the electrode material. The range of polarization depends on the composition and acidity of the main electrolyte and on average it ranges from +0.2 to $-1.5 \mathrm{~V}$. Because of the relatively narrow range of anodic polarization the mercury electrode is most frequently used over a wide cathodic range, thus reducing the depolarizers that are present in the solution.

The rapid development of genetics and bio-technology in recent years has induced intensive and detailed studies of properties of the basic components of nucleic acids: pirymidine and purine derivatives and respective nucleosides. ${ }^{17,18}$ The use of a charged interface on an electrode facilitates the obtaining of systems similar to those which can be found in living organisms close to an interface: charged cellular membrane/systemic fluid. The selection of a mercury electrode featuring perfect polarisability facilitates the use of various thermo-dynamic dependencies, which in turn facilitate a thorough description of properties of the studied organic substance on the interface electrode/electrolyte solution.

The aim of the work was to describe the adsorptive properties of adenine by means of the parameters of the virial isotherm and the Frumkin isotherm and to study the effect of adenine on $\mathrm{Zn}$ (II)ion electro-reduction on a mercury electrode.

The use of $\mathrm{Zn}$ (II)ions as a depolarizer results from their quasi-reversible reduction on the mercury electrode. One can observe the change in kinetics of the reaction, both as concerns its inhibition and acceleration. The fact that zinc obtained as a result of reduction readily forms an amalgam with mercury is another advantage.

The attractiveness of $\mathrm{Zn}$ (II)ions as a depolarizer is also related to the fact that the determined kinetic param- eters of its electroreduction make it possible in selected systems to examine indirectly the structure of the adsorption layer on the mercury electrode.

The bases for the calculation of these isotherms are values determined experimentally: differential capacity of the double layer, potential of zero charge and surface tension at this potential.

By means of cyclic voltammetry and Faraday impedance, different effects of adenine in acetate buffers at $\mathrm{pH} 3$ and $\mathrm{pH} 4$ on the kinetics of $\mathrm{Zn}$ (II)ion electro-reduction were demonstrated.

\section{Experimental}

Studies of adsorptive properties of adenine on a mercury electrode were performed in buffers at $\mathrm{pH} 3,4,5$ and 6 and the presented work concerns the studies of the adsorptive properties of adenine in acetate buffers at $\mathrm{pH} 3$ and 4 . The adsorption of adenine on a mercury electrode in acetic buffers at $\mathrm{pH} 3$ and 4 is described by means of the adsorption isotherms constants calculated from the surface pressure as a function of electrode potential and adsorbate bulk concentration. The adsorption parameters from the double-layer were calculated based on the data from the differential capacity-potential curves.

Analytical grade $\mathrm{C}_{5} \mathrm{H}_{5} \mathrm{~N}_{5}$ and $\mathrm{CH}_{3} \mathrm{COOH}$ and $\mathrm{CH}_{3} \mathrm{COONa}$ (Fluka) were used without further purification. Water and mercury were double distilled before use. The adenine solutions of concentrations, ranging from $5 \times$ $10^{-5} \mathrm{~mol} \mathrm{~L}^{-1}$ to $2 \times 10^{-3} \mathrm{~mol} \mathrm{~L}^{-1}$, were prepared immediately before every measurement. The chosen surfactant concentrations were lower than the surfactant critical micelle concentration. The solutions were deaerated by passing high purity nitrogen over the solution during the measurements, at $298 \pm 0.1 \mathrm{~K}$. The three-electrode system was used, with a dropping mercury electrode as a working electrode, and an $\mathrm{Ag} / \mathrm{AgCl}$ as a reference electrode, to which all potentials in this paper are referred, and a platinum electrode as the auxiliary electrode. A controlled growth mercury drop electrode (area $0.0090928 \mathrm{~cm}^{2}$ ) (CGMDE), manufactured by MTM (Poland), was used. The differential capacity, $\mathrm{C}$, of the double layer was measured with an Autolab frequency response analyser, (Eco Chemie, The Netherlands), using the AC impedance technique. The repeatability of the capacitance measurements was $\pm 5 \%$. The measurements were carried out at several frequencies in the range from 400 to $2000 \mathrm{~Hz}$, with an amplitude of $0.05 \mathrm{~V}$. The equilibrium capacities were obtained by the extrapolation of the dependence of the measured capacity versus the square root of the frequency to zero frequency.

The potential of zero charge, $\mathrm{E}_{\mathrm{z}}$, was measured using a streaming electrode. The interfacial tension, $\gamma_{z}$, at $E_{z}$ was measured by the maximum bubble pressure method according to Schiffrin. The accuracy of determination of $\gamma_{z}$ 
was $\pm 0.2 \mathrm{mN} \mathrm{m}^{-1}$. The charge density and surface tension were obtained by the back integration of the differential capacity-potential dependences. No corrections were made for the effect of the medium on the activity of the supporting electrolyte ${ }^{19,20}$ and the activity coefficient of the adsorbate.

The $\mathrm{Zn}(\mathrm{II})$ ions electro-reduction studies were performed by means of the cyclic voltammetry and measurement of Faraday impedance using the Autolab frequency response analyser.

\section{Results and Discussion}

\section{1. Analysis of Experimental Data}

The experimental data and calculated thermo-dynamic parameters presented herein are related to the adsorption of adenine from an acetate buffer, each with a different $\mathrm{pH}$, allowing supplementing the information about the mechanism of adsorption of this compound on a mercury electrode.

The differential capacity of the double layer was the main source of experimental data that were used to determine adsorption parameters for the examined systems. Measurements of differential capacity were made at various AC frequencies. Differential capacity values for the double layer obtained in direct measurements were extrapolated to zero frequency. This ensures obtaining capacity values corresponding to the equilibrium of the adsorption-desorption process. Figure 3 present the correlations between the extrapolated differential capacity of the double layer and the electrode potential at various adenine concentrations in the applied acetate buffers.

The analysis of the curves of differential capacity indicates a totally different change in differential capacity in an acetate buffer at $\mathrm{pH} 3$ in comparison to a buffer at $\mathrm{pH} 4$ in the absence of adenine. The minimum differential capacity is observed in the buffer at $\mathrm{pH} 3$ with $\mathrm{E}=-0.5 \mathrm{~V}$, whereas in the buffer at $\mathrm{pH} 4$ the capacity decreases. In both buffers without adenine at $\mathrm{E}>-0.8 \mathrm{~V}$, the values of differential capacity are practically constant. A different shape of the curves of differential capacity without adenine for $\mathrm{pH} 3$ in comparison to $\mathrm{pH} 4$ may result from stronger adsorption of acetic acid molecules in the buffer at $\mathrm{pH} 3$.

In the case of the acetate buffer at $\mathrm{pH} 3$, the addition of adenine in the solution causes various changes in the differential capacity in the function of its concentration and electrode potential. The nature of the changes in the shape of the curves $\mathrm{C}=\mathrm{f}(\mathrm{E})$ for adenine solutions in comparison to the curve for the basic electrolyte indicates different effects in two areas of potential $\mathrm{E}>-0.65 \mathrm{~V}$ and $\mathrm{E}<$ $-0.65 \mathrm{~V}$. With less negative potentials, an increase in the value of the differential capacity of adenine is observed, whereas for the area of potentials $\mathrm{E}<-0.65 \mathrm{~V}$ a lowering of the curve $\mathrm{C}=\mathrm{f}(\mathrm{E})$ for adenine solutions is observed and is

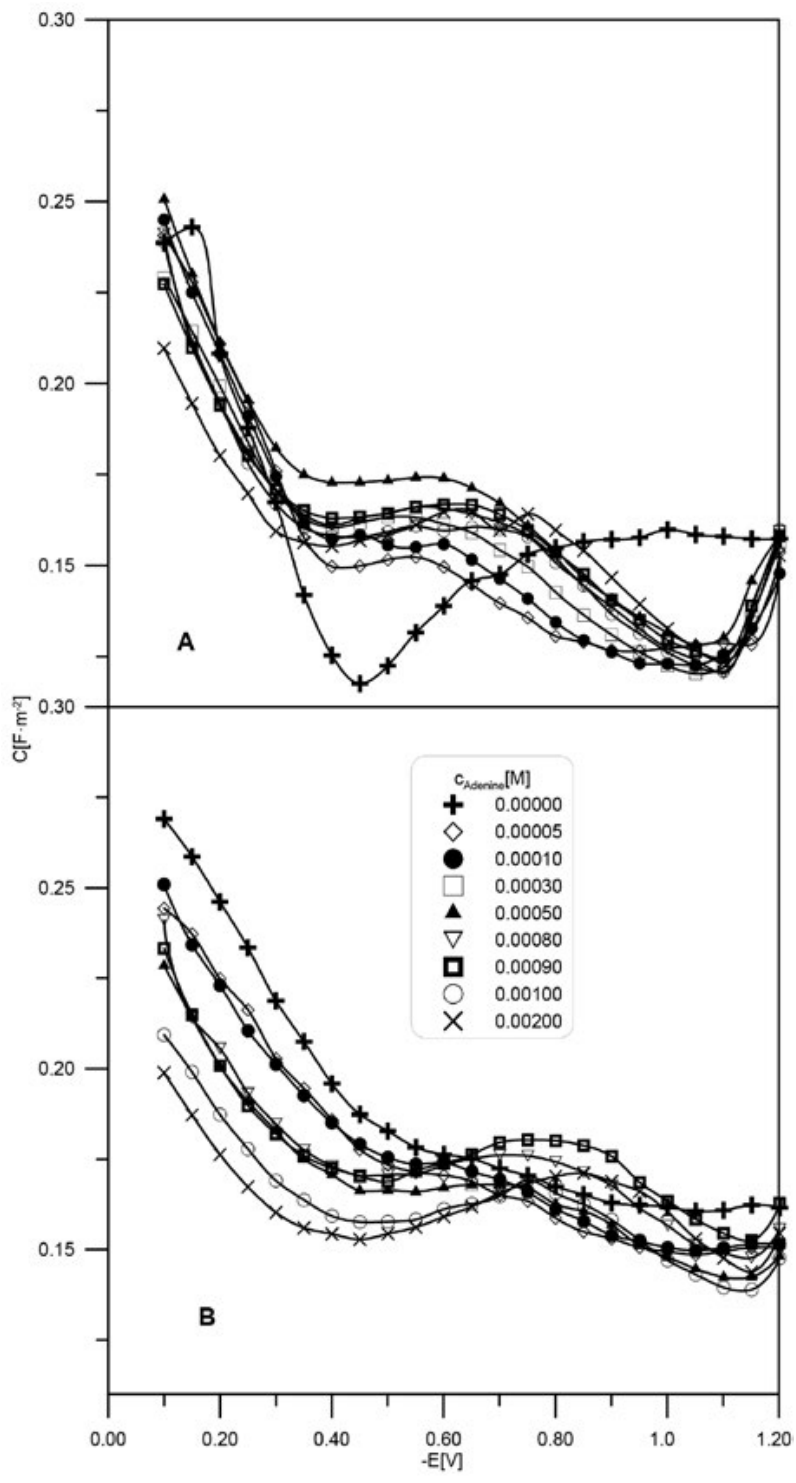

Figure 3. The differential capacity-potential curves at $\mathrm{Hg} /$ acetic buffer $\mathrm{pH} 3$ (A) $\mathrm{pH} 4$ (B) for various adenine concentrations as in figure legend.

the greatest with the lowest of all the applied concentrations. The values of potential for which the curve of differential capacity of the buffer at $\mathrm{pH} 3$ crosses the respective curves for adenine and turn to values which are more negative with an increase in adenine concentration. An increase in adenine concentration causes an increase in the value of the differential capacity practically in the whole range of potentials.

Three areas of potential can be distinguished in the shape of the curves for the differential capacity for buffers at $\mathrm{pH} 4:-0.2 \mathrm{~V}<\mathrm{E}<-0.65 \mathrm{~V}$ and $-0.65 \mathrm{~V}<\mathrm{E}<-1.0 \mathrm{~V}$ and $-1.0 \mathrm{~V}<\mathrm{E}<-1.2 \mathrm{~V}$. The first area features a gradual decrease in the differential capacity with an increase in adenine concentration. With a potential of approx. $-0.65 \mathrm{~V}$, curves for the differential capacity cross. In the second area of potentials, the differential capacity in the presence 
of higher adenine concentrations is generally higher than the values obtained for the stock solution. For lower adenine concentrations, the differential capacity is lower. With a potential more negative than $-1.0 \mathrm{~V}$, a decrease in the differential capacity is observed for all adenine concentrations as opposed to the standard electrolyte. This may be a consequence of changes in mutual interactions, mainly electrostatic, between adsorbed molecules. Increasing the differential capacity by adenine may be a result of chemical interaction of the aromatic ring of adenine with the surface of the mercury electrode.

As Table 1 indicates, $\mathrm{E}_{\mathrm{z}}$ values in buffer solutions with increasing $\mathrm{pH}$ without adenine shift toward negative potentials, which is associated with an increased concentration of acetate anions. The addition of adenine to the standard electrolyte at $\mathrm{pH} 3$ causes a shift of $\mathrm{E}_{\mathrm{z}}$ toward less negative potentials, whereas in an acetate buffer at $\mathrm{pH} 4$ causes a shift toward more negative potentials. Such changes in the potential of zero charge $\mathrm{E}_{\mathrm{z}}$, with an increase in adenine concentration in an acetate buffer at $\mathrm{pH} 4$ indicate that a dipole molecule of adenine adsorbs on the surface of mercury with the negative pole, i. e. with the aromatic ring.

In the buffer at $\mathrm{pH} 3$, the adenine molecule is more strongly protonated and adsorbs on the mercury electrode with the positive pole.

In the absence of any organic substance, $\gamma_{z}$ values increase with an increase in $\mathrm{pH}$ of the basic electrolyte. In each of the considered systems, the introduction of lower adenine concentrations causes an increase in $\gamma_{\mathrm{z}}$ values, whereas higher adenine concentrations lower $\gamma_{z}$ values. Changes in $\mathrm{E}_{\mathrm{z}}$ and $\gamma_{\mathrm{z}}$ in the function of adenine concentration are similar in both of the used buffers.

The results of measurements of the potential of zero charge and the surface tension with this potential served as the constant of integration for differential capacity curves. On the basis of dependence 1, charge density on the surface of the electrode is obtained.

$$
\sigma=\int_{E_{z}}^{E} C d E
$$

Table 1. The values of the zero charge potentials $\mathrm{E}_{\mathrm{z}} \mathrm{vs} \mathrm{Ag} / \mathrm{AgCl}$ electrode and surface tension $\gamma_{z}$ at $E_{z}$ for the studied systems.

\begin{tabular}{|c|c|c|c|c|}
\hline \multirow[t]{2}{*}{$\mathrm{c} / \mathrm{mol} / \mathrm{L}$} & \multicolumn{2}{|c|}{ pH 3} & \multicolumn{2}{|c|}{ pH 4} \\
\hline & $-\mathbf{E}_{\mathrm{z}} / \mathrm{V}$ & $\gamma_{\mathrm{z}} / \mathrm{mN} \mathrm{m}^{-1}$ & $-\mathrm{E}_{\mathrm{z}} / \mathrm{V}$ & $\gamma_{\mathrm{z}} / \mathrm{mN} \mathrm{m}^{-1}$ \\
\hline 0 & 0.38 & 453 & 0.41 & 417 \\
\hline $5.0 \cdot 10^{-5}$ & 0.39 & 465 & 0.40 & 469 \\
\hline $1.0 \cdot 10^{-4}$ & 0.39 & 465 & 0.40 & 465 \\
\hline $3.0 \cdot 10^{-4}$ & 0.39 & 455 & 0.40 & 458 \\
\hline $5.0 \cdot 10^{-4}$ & 0.38 & 456 & 0.40 & 458 \\
\hline $8.0 \cdot 10^{-4}$ & 0.38 & 451 & 0.40 & 453 \\
\hline $9.0 \cdot 10^{-4}$ & 0.38 & 449 & 0.40 & 452 \\
\hline $1.0 \cdot 10^{-3}$ & 0.38 & 448 & 0.40 & 449 \\
\hline $2.0 \cdot 10^{-3}$ & 0.37 & 445 & 0.41 & 446 \\
\hline
\end{tabular}

Twofold integration of differential capacity curves serves to calculate the value of surface tension in accordance with equation 2 .

$$
\gamma=\gamma_{Z}-\int_{E_{Z}}^{E} \int C d E
$$

The obtained values of surface charge were used to determine parameters characterising the maximum adsorption: potential of the maximum adsorption $\mathrm{E}_{\max }$ and charge of the maximum adsorption $\sigma_{\max }$ (Figure 4).

Respectively, for $\mathrm{pH} 3, \mathrm{E}_{\max }=0.34 \mathrm{~V}, \sigma_{\max }=+0.43 \times$ $10^{-2} \mathrm{C} \mathrm{m}^{-2}$ and for $\mathrm{pH} 4, \mathrm{E}_{\text {max }}=0.33 \mathrm{~V}, \sigma_{\max }=+1.12 \times 10^{-2} \mathrm{C}$ $\mathrm{m}^{-2}$. The possibility of accurate determination of $\mathrm{E}_{\max }$ and $\sigma_{\max }$ indicates a physical nature of adenine adsorption (physisorption).

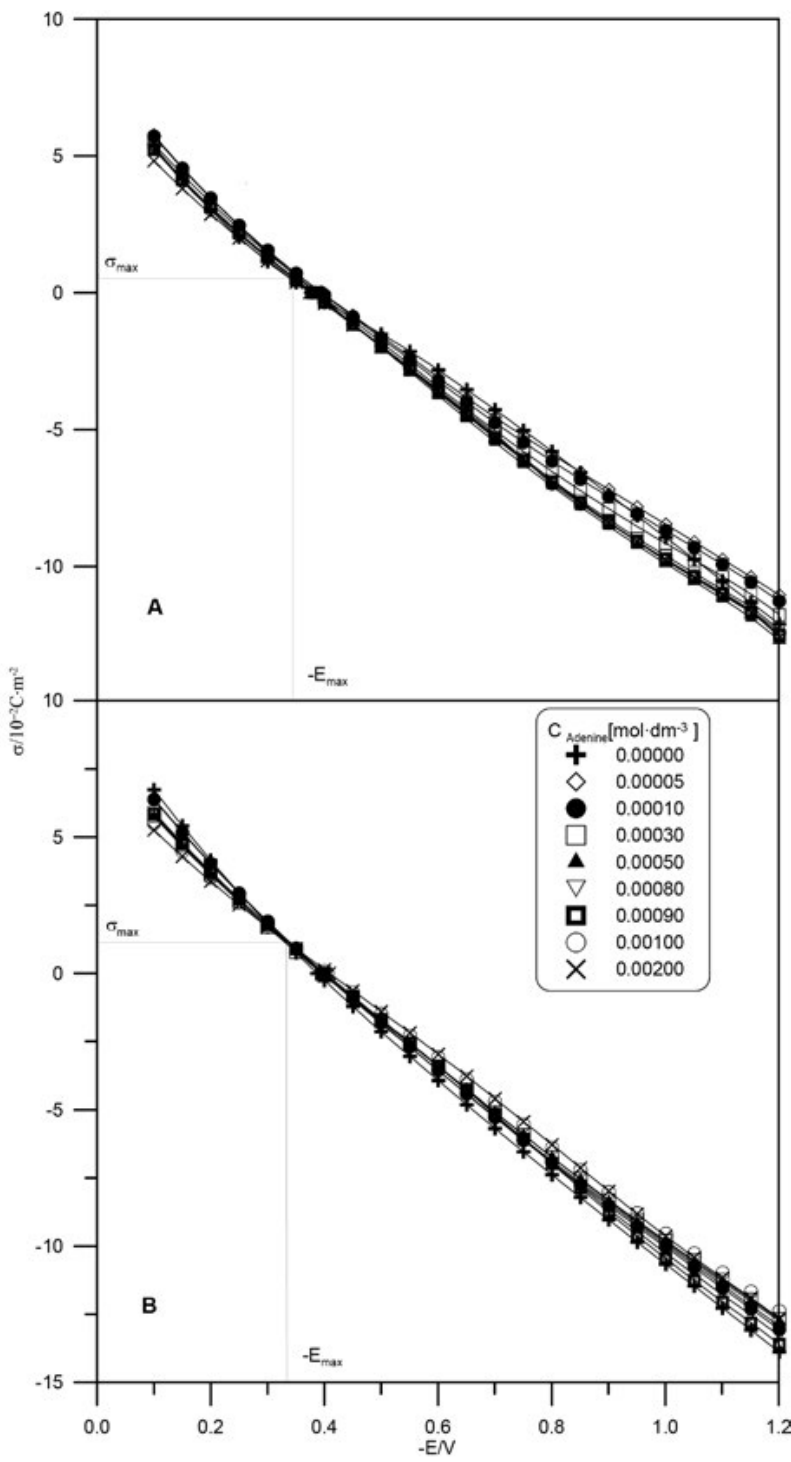

Figure 4. Correlation between the surface charge density on mercury and the potential of the electrode for an acetate buffer at $\mathrm{pH} 3$ (A) and $\mathrm{pH} 4$ (B) in the function of adenine concentration. 


\section{2. Adsorption Isotherms}

The adsorption of adenine was described using the relative surface excess, $\Gamma$, which, according to the Gibbs adsorption isotherm, is given by:

$$
\Gamma^{\prime}=\frac{1}{R T}\left(\frac{\partial \Phi}{\partial \ln c}\right)_{E}
$$

where $\mathrm{c}$ is the bulk concentration of adenine and $\Phi$ is the surface tension, as in $\Phi=\gamma_{0}-\gamma$, where $\gamma_{0}$ is the surface tension of the basic electrolyte, and $\gamma-$ is the surface tension for the solution containing adenine.

Values of adenine surface concentrations expressed as relative surface excess were analysed in order to obtain

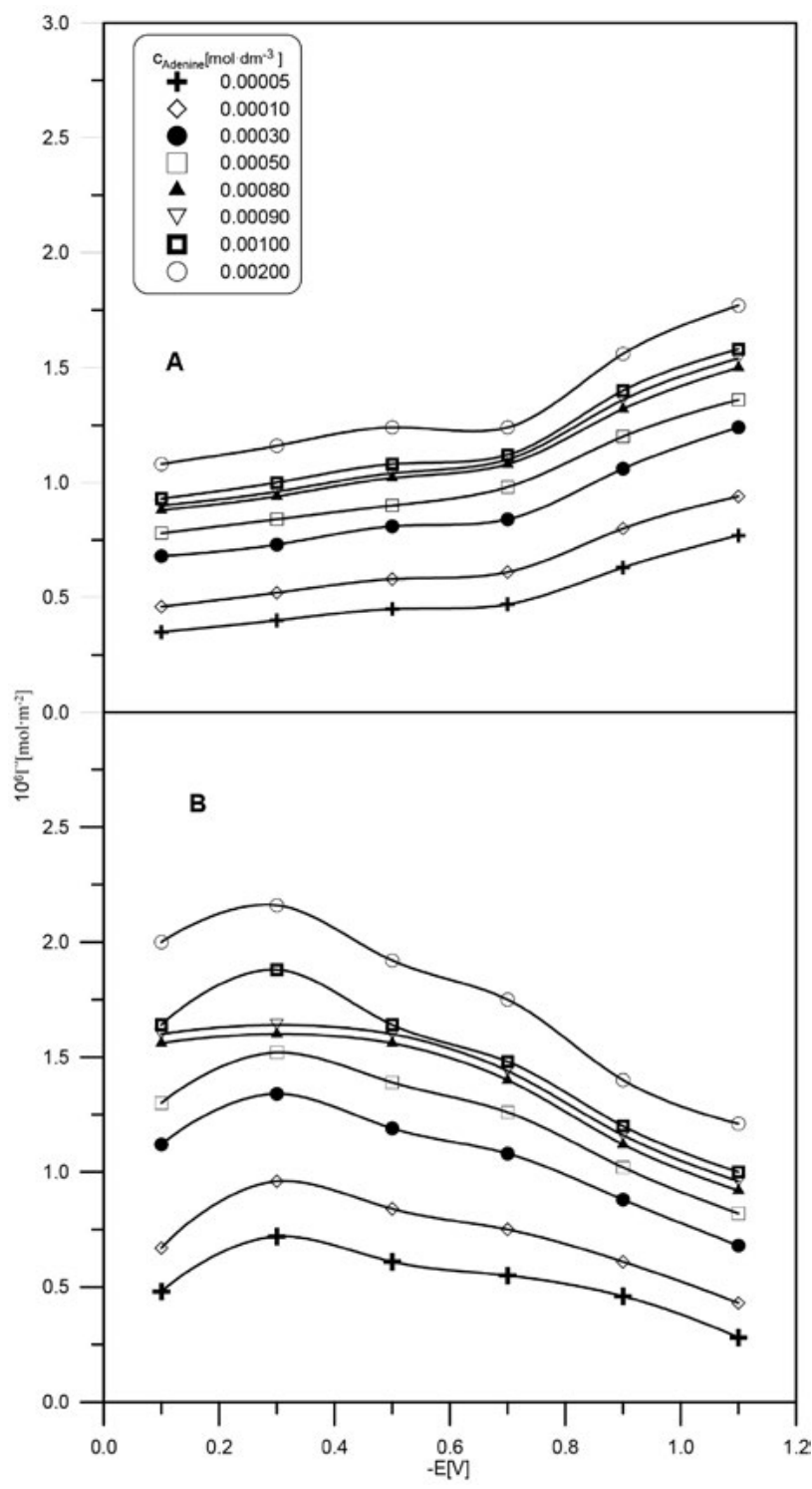

Figure 5. Relative surface excess of adenine as a function of the potential and adenine concentration in the bulk, in the acetic buffers $\mathrm{pH} 3$ (A) and $\mathrm{pH} 4(\mathrm{~B})$. a more complete picture of the adsorption of the tested substance (Figure 5).

The course of changes in the values of relative surface excess $\Gamma$ ' for each of the studied systems is different. Presumably, it is caused by the fact that in the acetate buffer at $\mathrm{pH} \mathrm{3,} \mathrm{a} \mathrm{molecule} \mathrm{of} \mathrm{adenine} \mathrm{adsorbs} \mathrm{on} \mathrm{the} \mathrm{surface} \mathrm{of} \mathrm{a}$ mercury electrode with the positive pole. An increase in surface excess for adenine toward less negative potentials indicates electro-static interaction between a protonated molecule of adenine with an increasingly negatively charged surface of a mercury electrode. In the acetate buffer at $\mathrm{pH} \mathrm{4,} \mathrm{a} \mathrm{dipole} \mathrm{molecule} \mathrm{of} \mathrm{adenine} \mathrm{absorbs} \mathrm{on} \mathrm{the}$ surface of mercury with the negative pole. Slightly bellshaped dependence $\Gamma^{\prime}=f(E)$ in the buffer solution at $\mathrm{pH} 4$ indicates a physical nature of adenine adsorption on a mercury electrode.

The adsorption of adenine was further analysed on the basis of constants obtained from the Frumkin isotherm. ${ }^{21-26}$ The Frumkin isotherm (Figure 6) constants were determined from the equation:

$$
\beta x=[\Theta /(1-\Theta)] \exp (-2 A \Theta)
$$

where $x$ is the mole fraction of adenine in the solution, $\beta$ is the adsorption coefficient: $\beta=\exp \left(-\Delta G^{o} / R T\right), \Delta G^{0}$ is the standard Gibbs energy of adsorption, A is the interaction parameter, and $\Theta$ is the coverage value $\left(\Theta=\Gamma^{\prime} / \Gamma_{s}\right)$. The face excess at saturation, $\Gamma_{s}$, was estimated by extrapolating the $1 / \Gamma$,vs. $1 / c_{C_{S} H_{5} N_{s}}$ lines at different electrode potentials to. $1 / c_{c_{S} H_{S} N_{S}}=0$. The $\Gamma_{S}$ value obtained this way was: $3.23 \times 10^{-6} \mathrm{~mol} \mathrm{~m}^{-2}$ for $\mathrm{pH} 3$ of the basic electrolyte and $3.45 \times 10^{-6} \mathrm{~mol} \mathrm{~m}^{-2}$ for $\mathrm{pH} 4$. The surface occupied by one adenine, $S\left(S \equiv 1 / \Gamma_{\mathrm{s}}\right)$, is $0.514 \mathrm{~nm}^{2}$ and $0.481 \mathrm{~nm}^{2}$ respectively for the buffer with a pH of 3 and a pH of 4 .

The obtained values are comparable and indicate a flat orientation of adsorbed adenine molecules in both systems.

The values of free energy $\Delta G_{F}^{0}$ and adsorption factor $-\mathrm{A}_{\mathrm{F}}$ obtained in linear tests of the Frumkin isotherm are presented in Table 2.

The values of parameter $-A_{F}$ in both buffers indicate a repulsive interaction between adsorbed adenine molecules, but in the buffer at $\mathrm{pH} 3$ this interaction is increasingly weaker toward less negative potentials, whereas in the buffer at $\mathrm{pH} 4$ the repulsive interaction clearly intensifies toward more negative potentials. Changes in the repulsive interaction between adsorbed molecules of adenine insignificantly affect a change in adsorption energy. 


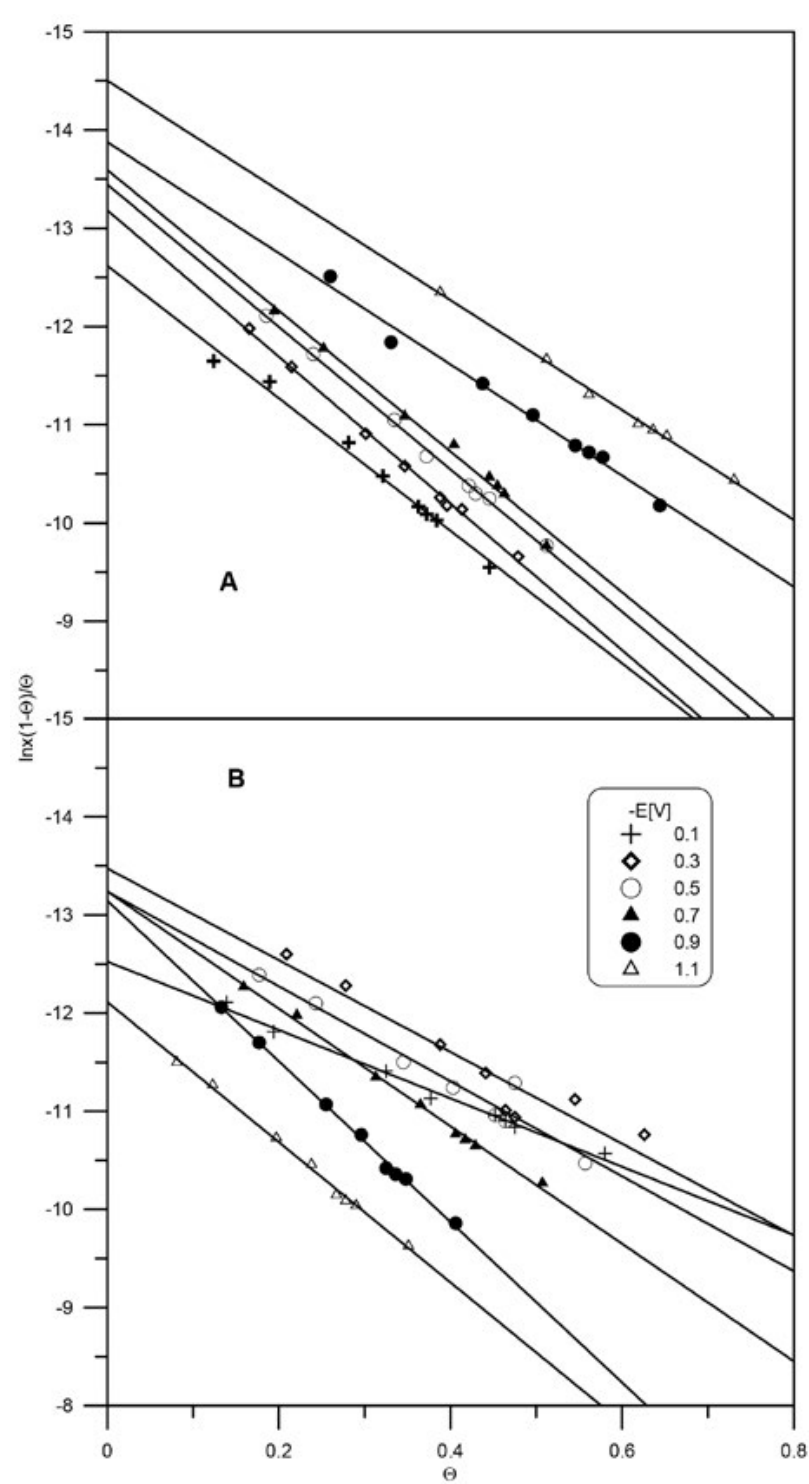

Figure 6. Linear test of the Frumkin isotherm in the system acetic buffer $\mathrm{pH} 3$ (A) and $\mathrm{pH} 4$ (B) + adenine for different electrode potentials.

Values of adsorption energy in both buffers are comparable except that in the buffer at $\mathrm{pH} 3$ they increase (in an absolute sense) toward more negative potentials, which indicates electro-static interaction between a protonated molecule of adenine and the surface of an electrode. In the acetate buffer at $\mathrm{pH} 4$, these values display slight dependence on potential.

The previously presented Frumkin isotherms are encumbered with errors resulting from discrepancies between theoretical and experimental values $\Gamma_{\mathrm{s}}$. Therefore, virial isotherms in which the parameter does not occur were used to check adsorption parameters.

By means of the linear test of the virial isotherm, values of the second virial factor $B$ were determined from the slopes of the lines whereas values of adsorption energy $\Delta G_{V}^{0}$ were obtained by extrapolating these lines to value $\Gamma^{\prime}$

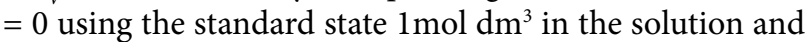
1 molecule $\mathrm{cm}^{-2}$ on the surface of the electrode.

The obtained values of adsorption energy and the second virial factor B in the function of electrode potential are presented in Table 2. The trends in changes in adsorption parameters obtained from the virial isotherm have a similar shape to those obtained from the Frumkin isotherm.

\section{3. Electroreduction Kinetics of $\mathrm{Zn}$ (II)ion in the Presence of Adenine in an Acetate Buffer at $\mathrm{pH} 3$ and $\mathrm{pH} 4$.}

Studies of the effect of adenine on kinetics of $\mathrm{Zn}^{2+}$ ion reduction were performed using various measurement techniques, e. g. cyclic voltammetry and measurement of Faraday impedance. ${ }^{22}$

Potentials of anode peak $\mathrm{E}_{\mathrm{a}}$ and cathode peak $\mathrm{E}_{\mathrm{k}}$ for $\mathrm{Zn}$ (II)ion reduction were determined from the shape of cyclic voltammetric curves, and the difference of potentials for anode and cathode peaks was calculated from dependence 5 .

$$
\Delta \mathrm{E}=\mathrm{E}_{\mathrm{a}}-\mathrm{E}_{\mathrm{k}}
$$

The differences of potentials for anode and cathode peaks are a good qualitative criterion of the assessment of reversibility of the electrode process. They are presented in Table 3.

On the basis of the obtained $\Delta \mathrm{E}$ values, it can be stipulated that $\mathrm{Zn}$ (II) reduction reactions are irreversible in

Table 2. The constants of Frumkin $(\mathrm{F})$ and virial $(\mathrm{V})$ isotherms for the system: the acetic buffer $\mathrm{pH} 3$ and $\mathrm{pH} 4+$ adenine; $\mathrm{E},-\Delta G^{0}, \mathrm{~B}$.

\begin{tabular}{|c|c|c|c|c|c|c|c|c|}
\hline \multirow[b]{2}{*}{$-\mathrm{E} / \mathrm{V}$} & \multicolumn{4}{|c|}{ pH 3} & \multicolumn{4}{|c|}{ pH 4} \\
\hline & $\begin{array}{c}\Delta G_{F}^{0} / \mathbf{k J} \\
\mathbf{m o l}^{-1}\end{array}$ & $-\mathbf{A}_{F}$ & $\begin{array}{c}\Delta G_{V}^{0} / \\
\mathbf{k J} \mathbf{~ m o l}^{-\mathbf{1}}\end{array}$ & $\begin{array}{c}\text { B / } \\
\mathbf{n m}^{2} / \text { molecula }\end{array}$ & 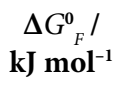 & $-A_{F}$ & $\begin{array}{c}\Delta G_{V}^{\mathbf{0}} / \mathbf{k J} \\
\mathbf{m o l}^{-1}\end{array}$ & $\begin{array}{c}\text { B / } \\
\mathbf{n m}^{2} / \text { molecula }\end{array}$ \\
\hline 0.10 & 31.56 & 4.70 & 109.20 & 2.52 & 31.04 & 1.75 & 108.60 & 1.08 \\
\hline 0.30 & 32.45 & 4.80 & 110.20 & 2.52 & 33.04 & 2.10 & 111.10 & 1.30 \\
\hline 0.50 & 33.49 & 4.90 & 110.70 & 2.52 & 32.80 & 2.47 & 110.60 & 1.43 \\
\hline 0.70 & 33.56 & 4.60 & 111.00 & 2.38 & 32.80 & 3.00 & 110.20 & 1.55 \\
\hline 0.90 & 34.21 & 3.70 & 112.30 & 2.12 & 32.65 & 4.13 & 109.40 & 1.91 \\
\hline 1.10 & 35.42 & 3.50 & 113.70 & 2.06 & 30.37 & 4.13 & 107.40 & 1.77 \\
\hline
\end{tabular}


Table 3. Values of potentials anodc and cathodic peaks and their difference for the system: $5 \times 10^{-3} \mathrm{~mol} \mathrm{~L}^{-1}$

$\mathrm{Zn}(\mathrm{II})$ in the buffer solutions at $\mathrm{pH} 3$ and $\mathrm{pH} 4$ without adenine and for various adenine concentrations.

\begin{tabular}{lcccccr}
\hline $\begin{array}{l}\mathbf{C}_{\text {adenine } /} \\
\text { mol/L }\end{array}$ & $-\mathbf{E}_{\mathbf{a}} / \mathbf{V}$ & $\begin{array}{c}\mathbf{p H ~ 3} \\
-\mathbf{E}_{\mathbf{k}} / \mathbf{V}\end{array}$ & $\mathbf{\Delta E} / \mathbf{V}$ & $-\mathbf{E}_{\mathbf{a}} / \mathbf{V}$ & $\begin{array}{c}\mathbf{p H ~ 4} \\
-\mathbf{E}_{\mathbf{k}} / \mathbf{V}\end{array}$ & $\Delta \mathbf{E} / \mathbf{V}$ \\
\hline 0 & 0.90 & 1.05 & 150 & 0.92 & 1.02 & 98 \\
$5.0 \cdot 10^{-5}$ & 0.82 & 1.05 & 228 & 0.92 & 1.02 & 105 \\
$1.0 \cdot 10^{-4}$ & 0.81 & 1.05 & 236 & 0.92 & 1.02 & 105 \\
$3.0 \cdot 10^{-4}$ & 0.81 & 1.05 & 244 & 0.92 & 1.03 & 108 \\
$5.0 \cdot 10^{-4}$ & 0.81 & 1.06 & 247 & 0.92 & 1.03 & 113 \\
$8.0 \cdot 10^{-4}$ & 0.81 & 1.06 & 252 & 0.92 & 1.03 & 109 \\
$9.0 \cdot 10^{-4}$ & 0.80 & 1.06 & 262 & 0.92 & 1.03 & 111 \\
$1.0 \cdot 10^{-3}$ & 0.80 & 1.07 & 262 & 0.92 & 1.03 & 112 \\
$2.0 \cdot 10^{-3}$ & 0.80 & 1.06 & 264 & 0.92 & 1.03 & 114 \\
$3.0 \cdot 10^{-3}$ & 0.78 & 1.07 & 274 & 0.92 & 1.03 & 114 \\
$4.0 \cdot 10^{-3}$ & 0.84 & 1.10 & 257 & 0.92 & 1.03 & 113 \\
$5.0 \cdot 10^{-3}$ & 0.80 & 1.07 & 268 & 0.92 & 1.03 & 114 \\
\hline
\end{tabular}

both buffer solutions and that adenine added to solutions has an irreversibility effect by decelerating the reduction reaction of zinc ions. In the buffer solution at $\mathrm{pH} 3$ without adenine, inhibition of $\mathrm{Zn}$ (II) reduction is stronger due to stronger adsorption of molecules of acetic acid. The addition of adenine to the buffer more significantly inhibits $\mathrm{Zn}$ (II) electro-reduction in comparison to the buffer at $\mathrm{pH}$ 4 . This is a consequence of stronger adenine adsorption in the buffer at $\mathrm{pH} 3$ (Table 2).

Measurement of Faraday impedance was used to verify the results obtained from cyclic voltammetry. Values of activation resistance $\mathrm{R}_{\mathrm{a}}$ were determined at potentials corresponding to minimal $\mathrm{R}_{\mathrm{a}}$ values. In both studied buffer solutions, an increase in $\mathrm{R}_{\mathrm{a}}$ is observed with an increase in adenine concentration (Table 4). The inhibiting effect is much more weaker in solutions at $\mathrm{pH} 4$. The determined $\mathrm{R}_{\mathrm{a}}$ values ( $\mathrm{pH} 4$ ) slightly increase in comparison to the values obtained at $\mathrm{pH} 3$. Such behavior can be the result of larger protonation level in acetate buffer at $\mathrm{pH} 3$ in

Table 4. Minimal values of activation resistance at given potentials in the system: $5 \times 10^{-3} \mathrm{~mol} \mathrm{~L}^{-1} \mathrm{Zn}$ (II) in buffer solutions at $\mathrm{pH} 3$ and $\mathrm{pH} 4$ in the presence of increasing adenine concentrations.

\begin{tabular}{lcccc}
\hline $\begin{array}{l}\mathbf{C}_{\text {adenine }} / \\
\text { mol dm }^{-3}\end{array}$ & $-\mathbf{E} / \mathbf{V}$ & $\mathbf{R}_{\mathbf{A}} / \mathbf{\Omega} \mathbf{~ c m}^{2}$ & $-\mathbf{E} / \mathbf{V}$ & $\mathbf{R}_{\mathrm{A}} / \mathbf{\Omega} \mathbf{~ c m}^{2}$ \\
\hline 0 & 0.98 & 3.88 & 0.97 & 0.85 \\
$5.0 \cdot 10^{-5}$ & 0.98 & 2.19 & 0.97 & 1.17 \\
$1.0 \cdot 10^{-4}$ & 0.98 & 2.59 & 0.97 & 1.33 \\
$3.0 \cdot 10^{-4}$ & 0.97 & 4.55 & 0.98 & 1.58 \\
$5.0 \cdot 10^{-4}$ & 0.98 & 6.38 & 0.98 & 1.79 \\
$8.0 \cdot 10^{-4}$ & 0.98 & 7.87 & 0.98 & 1.84 \\
$9.0 \cdot 10^{-4}$ & 0.98 & 8.47 & 0.98 & 1.95 \\
$1.0 \cdot 10^{-3}$ & 0.98 & 9.00 & 0.98 & 1.93 \\
$2.0 \cdot 10^{-3}$ & 0.98 & 11.90 & 0.98 & 2.02 \\
$3.0 \cdot 10^{-3}$ & 0.99 & 12.72 & 0.98 & 2.26 \\
$4.0 \cdot 10^{-3}$ & 1.00 & 13.51 & 0.98 & 2.15 \\
$5.0 \cdot 10^{-3}$ & 0.99 & 13.41 & 0.99 & 2.39 \\
\hline
\end{tabular}

comparison to the one in the solution at $\mathrm{pH} 4$. It causes stronger repulsive interactions between protonated molecules of adenine and $\mathrm{Zn}(\mathrm{II})$ ions. As a result, the access of depolarizer ions to the electrode surface is more difficult thus inhibiting effect of adenine is larger in $\mathrm{pH} 3$

\section{Conclusions}

Experimental data and the results of thermodynamic analysis concerning adenine adsorption on a mercury electrode in an acetate buffer at two $\mathrm{pH}$ values $(\mathrm{pH} 3$ and $\mathrm{pH} 4$ ) presented in the work helped to observe certain regularities.

The comparison of the shape of the differential capacity curves obtained in the function of adenine concentration indicates differences in the adsorptive properties of adenine between the acetate buffer at $\mathrm{pH} 3$ and the acetate buffer at $\mathrm{pH} 4$.

The shape of dependences of relative surface excess in the function of potential indicates a physical nature of adenine adsorption in the buffer at $\mathrm{pH} 4$, whereas electrostatic interaction between adsorbed molecules of adenine and the surface of the electrode occurs in the buffer at $\mathrm{pH} 3$.

The shift of the value of potential of zero charge $E_{z}$ with an increase in adenine concentration in the buffer at $\mathrm{pH} 4$ toward more negative potentials indicates the absence of interaction between $\pi$ electrons of the aromatic ring of adenine with the surface of the mercury electrode. In the case of the buffer at $\mathrm{pH} 3$, the direction of changes in $\mathrm{E}_{\mathrm{z}}$ depends on the adenine concentration.

Studies of the kinetics of Zn (II)ion electro-reduction using cyclic voltammetry and Faraday impedance measurement led to a conclusion that in the buffer at $\mathrm{pH} 3$, $\mathrm{Zn}$ (II) ion electro-reduction is more irreversible than in the buffer at $\mathrm{pH}$ 4. The addition of adenine has a slightly greater effect on the inhibition of the electrode process in 
a solution of $\mathrm{pH} 3$, in which the adenine molecule is more protonated than in a solution of $\mathrm{pH} 4$. The inhibitory effect of adenine most probably results from blocking the surface of the mercury adsorbing with organic molecules. It grows with increasing its concentration and decrease in the $\mathrm{pH}$ of the buffer solution.

\section{References}

1. S. A. Kuznetsov, M. Gaune-Escard, J. Electroanal. Chem. 2006, 595, 11-22. DOI:10.1016/j.jelechem.2006.02.036

2. L. Massot, P. Chamelot, L. Cassayre, P. Taxil, Electrochimica Acta. 2009, 54, 6361-6366.

DOI:10.1016/j.electacta.2009.06.016

3. J. Nieszporek, D. Gugała, D. Sieńko, J. Szaran, J. Saba, Electrochimica Acta. 2006, 51, 2278-2281.

DOI:10.1016/j.electacta.2005.03.079

4. B. Timmer, M. Sluyters-Renbach, J. H. Sluyters, Surface Science. 1969, 18, 44-61. DOI:10.1016/0039-6028(69)90266-0

5. M. Sciendo, Corrosion Science. 2008, 50, 2070-2077.

DOI:10.1016/j.corsci.2008.04.007

6. A.-R. El-Sayed, A. M. Shaker, H. M. A. El-Lateef, Corrosion Science. 2010, 52, 72-81. DOI:10.1016/j.corsci.2009.08.047

7. J. Zwierzykowska, Ochrona przed korozja, 1962, 101, 15-20.

8. F. Beck, Elektroorganische Chemie, Velag Chemie, Weinheim, 1974.

9. B. Wyrwas, A. Szymanski, Z. Lukaszewski, Anal Chim Acta. 1995, 305, 31.

10. Z. Lukaszewski, A. Szymanski, B. Wyrwas. Trac Trends Anal Chem. 1996, 15(10), 525.

DOI:10.1016/S0165-9936(96)00064-7

11. J. Lenik, Mater Sci Eng C. 2014, 45, 109-116.

DOI:10.1016/j.msec.2014.08.072

12. A. Avranas, U. Retter, K. Lunkenheimet, Journal of Colloid and Interface. 2000, 227, 398-407.

DOI:10.1006/jcis.2000.6870
13. X. Zhao, W. Jin, J. Chen, Z. Gao, F. Wang, Analytica Chimica Acta. 1994, 289, 163-169.

DOI:10.1016/0003-2670(94)80099-5

14. X. Zhao, W. Jin, J. Tang, Electroanalysis. 1996, 8, 370-374. DOI:10.1002/elan.1140080413

15. K-J. Huang, D-J. Niu, J-Y. Sun, C. -H. Han, Z. -W. Wu, Y. -L. Li, X. -Q. Xiong, Colloids and Surfaces B: Biointerfaces. 2011, 82, 543-549. DOI:10.1016/j.colsurfb.2010.10.014

16. J. R. De Weille, Introduction to Electrophysiological Methods and Instrumentation Franklin Bretschneider, Academic Press is an Imprint of Elsevier 2006.

17. C. Prado, F. Prieto, M. Rueda, J. Feliu, A. Aldaz, Electrochimica Acta. 2007, 52, 3168-3171. DOI:10.1016/j.electacta.2006.09.062

18. A. De Batisti, S. Trasatti, J. Electroanal. Chem. 1974, 54, 1-17. DOI:10.1016/S0022-0728(74)80375-X

19. D. M. Mohilner, H. Nakadomari, J Phys Chem. 1973, 77, 1594-1596. DOI:10.1021/j100631a024

20. D. M. Mohilner, L. M. Bowman, S. J. Freeland, H. Nakadomari, J. Electrochem. Soc. 1973, 120, 1658-1670. DOI:10.1149/1.2403324

21. A. Nosal - Wiercińska, Electroanalysis. 2014, 26, 1013-1023. DOI:10.1002/elan.201400010

22. D. M. Bastidas, P. P. Gomez, E. Cano, Rev. Metal. Madrid. 2005, 41, 98-106. DOI:10.3989/revmetalm.2005.v41.i2.192

23. M. A. Quiroz, F. Cordova, L. Salgado, M. Viniegra, Y. Meas, G. Diaz. Revista Mexicana de Fisica. 1995, 41, 386-395.

24. D. Gugała-Fekner, J. Nieszporek, D. Sieńko, Monatsh. fur Chemie. 2015, 146, 541-545. DOI:10.1007/s00706-014-1382-7

25. V. L. Kolev, K. D. Danov, P. A. Kralchevsky, G. Broze, A. Mehreteab. Langmuir, 2002, 18, 9106-9109. DOI: $10.1021 /$ la0259858

26. H. J. El-Aila, K. M. Elsousy, K. A. Hartany, Arabian Journal of Chemistry, 2016, 9, S198-S203.

DOI:10.1016/j.arabjc.2011.03.002

\section{Povzetek}

$\mathrm{V}$ prispevku je predstavljena termodinamična analiza adsorpcije adenina na živosrebrni elektrodi v acetatnem pufru pri pH 3 in pH 4. Z uporabo Frumkinove in virialne izoterme smo določili energijo in konstante adsorpcije. Izkazalo se je, da je adsorpcija v pufru pri pH 3 močnejša kot v pufri pri pH 4. Pri izvedbi ciklične voltametrije in meritvah Faradayeve impedance smo opazili inhibitorski učinek adenina na kinetiko elektro redukcije ionov Zn (II). 